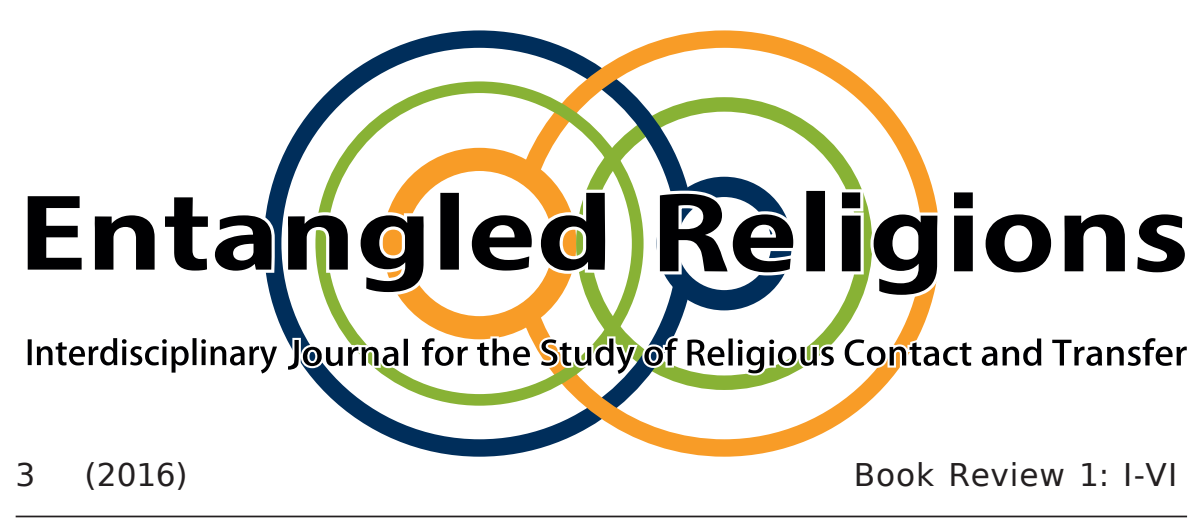

World Religions and Their Missions

New York: Peter Lang, 2015. 349 pages, €80.60, ISBN 978-14331-2284-2 (hardcover)/ISBN 978-1-4539-1419-9 (e-book)

AARON J. GHILONI (ED.)

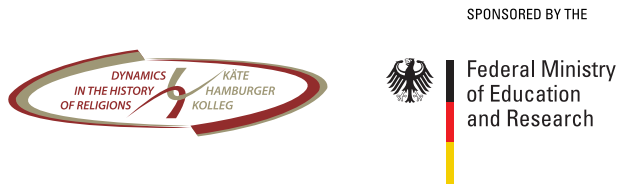




\title{
World Religions and Their Missions
}

\author{
New York: Peter Lang, 2015. 349 pages, \\ $€ 80.60$, ISBN 978-1-4331-2284-2 (hardcover)/ \\ ISBN 978-1-4539-1419-9 (e-book)
}

AARON J. GHILONI (ED.)

Considering the growing academic interest in comparative religion and interreligious dialogue, it is surprising that until recently there were no significant studies comparing attitudes to mission in the various religions around the globe. This volume, edited by Aaron Ghiloni from Trinity College Queensland (Australia), is therefore a very welcome contribution to the field of comparative religion. It treats the attitudes to mission of seven major religious traditions in alphabetical order: Atheism (by Jesse Smith), the Bahā'î faith (Robin Mihrshahi), Buddhism (Glenys Eddy), Christianity (Wendi Sargeant), Hinduism (Ferdinando Sardella), Islam (Mehmet Ozalp) and Mormonism (David Golding). Each chapter consists of ca. 30 pages, in which the authors set out the basic impulses, theories and methods of these traditions regarding bringing others to the faith. These chapters are followed by two stimulating chapters on the comparative study of mission (by Aaron Ghiloni) and the transformation of mission into interreligious dialogue (by Brian Adams).

One can see how outlining such a study brings immediate challenges. First of all, one could argue that the methods to spread religious messages are too varied among the religions to allow for meaningful comparisons. Secondly, in most cases the religions in question are labelled by umbrella terms (e.g. 'Hinduism') which mask the great variety of doctrines and practice, including forms of proselytizing (or lack of them). The editor of this volume deserves praise for proceeding with this project in defiance of such 
challenges. The outcome is an interesting juxtaposition of missionary ideas and practices in each of these religions, written in a lucid and accessible style.

Although the book is organized in separate chapters for each selected religion, a connecting theme is how missionary activity always worked in a plurireligious environment. An issue that is directly relevant, therefore, is the question of the consequences of one's exclusiveness. If one's beliefs are meant to be communicated to supposedly unenlightened others, then, besides bringing the good news, a tension with and condemnation of the beliefs of the others is present. Several chapters in the book explain how such interreligious tensions, created by belief in the truth of one's tradition, are handled. For instance Eddy explains that Buddhism, despite maintaining a claim to ultimate truth, acknowledges the different layers of truth that might be present in other religions. Hence there is no urgency to label others as heretics or unbelievers, nor a need to defend the dharma against outsiders' doctrinal challenges. According to Eddy, this tolerant attitude can also be seen as a determining factor in the branching out of Buddhism into communities that have quite diverse soteriological concerns. Tied to this question of the inherent tension with neighbouring religious traditions is the question of actual encounters with other communities. To what extent were there encounters and/or confrontations with communities that could be seen as rivals and to what extent were/are they directly targeted? There are numerous intriguing examples of historical entanglements throughout the book. Sardella, writing about Hindu mission, explains that Hindu missionary activity was directly inspired by Christian mission during the colonial period, during which Hindu missionaries recognized the importance of the press and of institutionalized religious education. At the same time, colonial Christian image-making of Hinduism as irrational, unethical (because of the caste system and gender division) and idolatrous, 
triggered a reformist and modernizing response within Hindu communities in the early $19^{\text {th }}$ century. Somewhat similarly, Eddy explains how Western Orientalist discourse in studies of Buddhism ignored living forms of the faith and focussed on its origins. This discourse impacted Buddhism in Asia and triggered new 'protestant' forms of Buddhism that equally sought pure forms of 'original' Buddhism and stimulated Buddhist missionary activity. Smith, writing on Atheism (which - rightly so - is not labelled as a 'religion'), describes how contemporary Atheists in the United States adopt the terminology of the religion they want to separate themselves from: 'the Sunday Assembly' of atheists ordains 'ministers' and has 'congregations' and a 'mission' to celebrate life.

Ozalp follows a different trajectory in his chapter on Islam. He describes the paradox of Islam's deeply engrained tradition of spreading the message of the Prophet without an actual development of missionary institutions. He then proceeds to explain how in the recent centuries the most persistent efforts to strengthen Islam have been efforts directed inwardly, i.e. to existing Muslim communities. Beginning in the early twentieth century, several movements arose that propagated a renewed spiritual awakening, giving rise to well-known revivalist movements. Ozalp's chapter is the only one in the book that gives a somewhat pious interpretation of the religion's beginnings. The consensus of modern scholarship is that 'Islam' in its early phase called the Arabs to join a movement that had no universal claims to superseding the surrounding religions, notably Judaism and Christianity. Ozalp's conflation of the Qur'ānic message and the later elaborations in the hadith creates a simplified version of Islam's complex beginnings. It may be true that Muhammad "would win over his staunchest enemies with kindness, consideration, and love" (p. 200) and that he soon had 100.000 followers (p. 201), but there is much in early Islamic and non-Islamic sources to indicate that allegiance to Muhammad was temporary and political. For 
this reason, I would recommend another recent publication that covers the same terrain but in a less romanticized way. That is Marcia Hermansen's chapter "'Conversion' to Islam in Theological and Historical Perspectives" in The Oxford Handbook of Religious Conversion, ed. by L.R. Rambo and C.E. Farhadian, Oxford, 2014, pp. 632-666.

What the book does not tell us is how the message of missionaries is received. We hear of Mormon preachers ritually shaking off the dust of their feet when they are rejected at the door of people they are trying to reach out to. But what about the people who do respond to the call? What is it that makes mission successful, at least in some cases? How come itinerant Sufi preachers had tremendous success in South Asia? How come Mormonism, a rather new religion, has managed to draw in millions of people? These are questions which bring us to the closely related fields of religious conversion and apologetics. It is obvious that the book cannot venture too far into the processes of conversion, but brief discussions of these would have helped to make the diverse concepts of mission more tangible.

In the two final discussions Ghiloni and Adams discuss mission in the light of interreligious dialogue. If in the modern day and age pluralism and ecumenism have become ideals, then what place is there left in society for one-directional preaching? Ghiloni argues that interreligious dialogue should not be seen as the antithesis of mission but rather as an opportunity to transform mission into interreligious education. Taking this idea further, Adam proposes a detailed framework for interreligious dialogue that is democratic, rational and reflective. This framework embodies a dialogic ideal that as yet is rarely played out. Yet it makes sense to invite religious educators to experiment with dialogue in Adam's proposed setting devoid of power relations and with a focus on the common good. Whether participants in such dialogues will feel they have genuine space to voice 
their beliefs in ways that may convince others is an open question. The answer to it will form the next chapter in the history of mission.

\section{BARBARA ROGGEMA}

King's College London 